\title{
MARKET POWER PERBANKAN INDONESIA
}

\author{
Andi Fahmi Lubis ${ }^{1}$
}

\begin{abstract}
This study was aimed to estimate the degree of market power exercised by commercial banks in credit market in Indonesia.Model used to answered this study's objective was Bresnahan-Lau oligopoly model that using structural equations to estimate the degree of market power. This model was using very different approach than Structure-Conduct-Performance (SCP) paradigm that commonly used in market power studies. Without using actual cost data and accounting profit, Bresnahan-Lau model was able to estimate directly the degree of market power from structural equations. The main result of this study was the degree of market power exercised by commercial banks in credit market relatively low; in other words the degree of competition in credit market in Indonesia was quite high.
\end{abstract}

Keywords: market power, oligopoly, Bresnahan-Lau, structure, performance, conduct, SCP. JEL Classification : L13, G21

1 Penulis adalah staf pengajar pada Magister Perencanaan dan Kebijakan Publik FEUl; andi.fahmi@ui.ac.id. Pandangan dan kesimpulan dalam paper ini semata-mata merupakan tanggung jawab penulis dan tidak mewakili pandangan institusi atau pihak lain. Penulis berterima kasih kepada anonymous referee atas komentar dan saran dalam paper ini. 


\section{PENDAHULUAN}

Market power adalah suatu ukuran kinerja yang menunjukkan seberapa besar kemampuan perusahaan untuk menaikkan harga di atas biaya marjinal (Church dan Ware, 2000). Jika dikaitkan dengan bentuk struktur pasar, perusahaan di pasar persaingan sempurna tidak memiliki market power, sedangkan perusahaan di pasar monopoli memiliki tingkat market power yang paling besar. Dengan demikian dapat ditarik kesimpulan bahwa semakin kompetitif sebuah pasar berarti semakin rendah market power yang ada, dan sebaliknya semakin pasar tidak kompetitif, market poweryang ada di pasar tersebut akan menunjukkan tingkatan yang semakin tinggi.

Analisa mengenai tingkat persaingan yang terjadi di suatu pasar dengan menggunakan ukuran market power telah menjadi fokus utama dalam kajian ekonomi industri, termasuk di dalamnya analisa tingkat persaingan di industri perbankan.Sebagai sebuah industri yang berfungsi sebagai lembaga intermediasi antara pihak yang memiliki kelebihan dana (surplus spending unit) dengan pihak yang memerlukan dana, maka peran perbankan sangat vital dalam menunjang proses pembangunan. Jika terjadi distorsi pada fungsi industri perbankan, sehingga memunculkan kinerja yang inefisien, maka proses mediasi antara pihak yang memerlukan dana dengan pemilik dana akan mengalami hambatan. Dengan adanya hambatan tersebut, maka dana yang ada tidak dapat digunakan untuk membiayai proyek-proyek pembangunan.

Melihat pentingnya fungsi perbankan bagi perkembangan perekonomian, pemerintah akan berusaha menjaga agar industri perbankan tetap dapat menjalankan fungsi mediasi yang diembannya. Berbagai kebijakan akan dikeluarkan pemerintah untuk meningkatkan efisiensi di industri perbankan.Industri perbankan Indonesia mulai mengalami perkembangan yang signifikan sejak dikeluarkannya paket deregulasi kebijakan pada tahun 1983, yang disebut Cole dan Slade (1996) sebagai Fase Reformasi 1983, yang kemudian dilanjutkan dengan Fase Pembebasan Hambatan Masuk pada tahun 1988, dengan paket kebijakan yang terkenal dengan istilah PAKTO 88. Dampak dari berbagai deregulasi tersebut adalah meningkatnya fungsi mediasi perbankan yang tercermin dari peningkatan nilai dana pihak ketiga yang dihimpun dan peningkatan nilai kredit yang disalurkan. Deregulasi tersebut juga diyakini berhasil meningkatkan efisiensi industri perbankan yang ditandai dengan menurunnya tingkat konsentrasi di industri perbankan.

Penurunan tingkat konsentrasi di suatu pasar akan berdampak positif terhadap efisiensi pasar didasarkan atas pandangan dari pendekatan Structure-Conduct-Performance (SCP), di mana baik buruknya kinerja suatu pasar sangat tergantung pada bentuk struktur pasar yang terjadi. Semakin terkonsentrasi pasar maka semakin besar kemampuan perusahaan untuk menaikkan harga di atas biaya marjinal, yang berarti market power yang diperoleh akan semakin tinggi. Tingginya market power tersebut diindikasikan sebagai semakin rendahnya tingkat persaingan. 
Indikasi tingkat persaingan berdasarkan konsentrasi yang terjadi menjadi dasar pembentukan hipotesis utama dari studi-studi berbasis pendekatan SCP. Tingkat konsentrasi industri perbankan Indonesia memang mengalami penurunan setelah deregulasi 1983 dan 1988, namun setelah periode tersebut cenderung stabil pada tingkat konsentrasi CR4 sebesar 40-50an dan CR8 sebesar 50-60an. Pada tabel 1 terlihat bahwa tingkat konsentrasi industri perbankan Indonesia masih berada pada tingkatan menengah, dan belum mencapai tingkatan kompetitif.

Analisa market power berdasarkan pendekatan SCP yang menggunakan struktur sebagai indikasi dari tingkat persaingan yang terjadi di pasar menimbulkan berbagai kritik. Diantaranya adalah adanya masalah endogenitas antara struktur dan kinerja, dimana pendekatan SCP mengasumsikan adanya hubungan searah antara struktur dan kinerja, sehingga kinerja yang dihasilkan di pasar dapat diindikasikan dari struktur yang terjadi. Kritik lain terkait dengan penggunaan accounting profit atau price cost margin (PCM) sebagai proksi dari selisih antara harga dengan biaya marjinal. Kelemahan yang melekat pada pendekatan SCP memunculkan pendekatan baru yang mencoba menganalisa tingkat persaingan yang terjadi di pasar tidak berdasarkan struktur, melainkan berdasarkan perilaku perusahaan yang ada di pasar. Pendekatan New Industrial Economics (NIE) dapat mengestimasi besarnya market power yang terjadi di sebuah pasar, yang kemudian digunakan sebagai indikator dari tingkat persaingan. Salah satu model estimasi yang menjadi bagian dari pendekatan baru ini adalah model oligopoli Bresnahan (1982) yang dikembangkan bersama Lau (1982).

Tujuan utama dari paper ini adalah menginvestigasi batas perilaku perbankan Indonesia dalam mempengaruhi harga, menjadi tujuan utama tulisan ini.Kemampuan perusahaan-

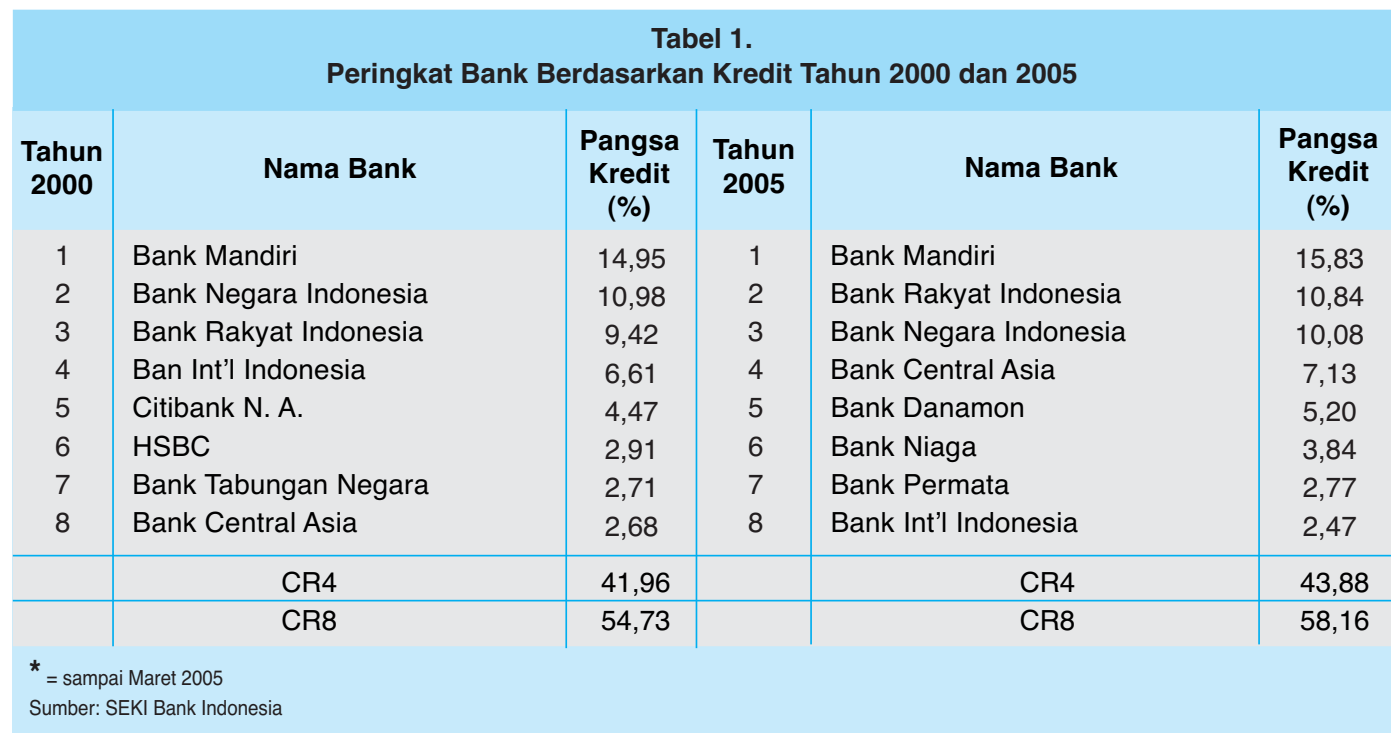


perusahaan di pasar dalam mempengaruhi harga menunjukkan seberapa besar market poweryang diberdayakan (exercising market power) sekaligus menunjukkan tingkat persaingan yang ada di dalam pasar tersebut. Apabila menilik struktur industri yang masih terkonsentrasi kepada beberapa bank, diduga tingkat persaingan yang ada di dalam industri perbankan Indonesia saat ini relatif rendah, yang juga mengindikasikan bahwa market power industri perbankan cukup tinggi. Hipotesis gabungan (joint hyphoteses) mengenai tingkat persaingan dan market power dari pasar kredit di industri perbankan Indonesia akan diukur dan diuji dengan menggunakan kerangka model oligopoli Bresnahan-Lau (BL).

Bagian kedua dari paper ini mengulas teori dan dasar penurunan model empiris yang akan diuji. Bagian ketiga mengulas metodologi sementara bagian keempat mengulas hasil estimasi dan analisisnya. Kesimpulan dan implikasi kebijakan disajikan pada bagian akhir dan menjadi bagian penutup.

\section{TEORI}

Pengukuran market power atau tingkat persaingan suatu industri dapat dibedakan atas dua pendekatan utama. Pendekatan pertama adalah pendekatan SCP tradisional yang didasarkan atas penggunaan data akuntansi yang berkaitan dengan profit dan biaya untuk mengukur market power. Pendekatan kedua yang muncul belakangan ini adalah pendekatan New Industrial Economics (NIE) atau New Empirical Industrial Organization (NEIO) yang mengurangi bahkan menghilangkan penggunaan data akuntansi untuk mengukur market power. Pendekatan NIE menggunakan kerangka struktural hubungan permintaan dan penawaran untuk mengestimasi market power. Pendekatan ini didasarkan atas pemikiran bahwa perusahaan yang ada di dalam pasar persaingan sempurna -yang bersifat price taker, dan perusahaan yang berada dalam pasar tidak sempurna -yang memiliki market power, akan memiliki reaksi yang berbeda atas perubahan eksogen pada permintaan dan penawaran (Church dan Ware, 2000).

Sebagai aliran yang bersifat rekonsiliasi (antara aliran SCP tradisional dan Chicago), Ekonomi Industri Baru bukan merupakan suatu aliran yang meraih 'popularitas'nya dengan cara 'menyerang' aliran lain, karena itu kita tidak dapat dengan mudah menentukan suatu titik balik atau garis pembatas yang jelas yang membedakannya dengan aliran-aliran sebelumnya. Namun paling tidak kita masih dapat menentukan ciri-ciri khusus yang membuat aliran ini mendapatkan imbuhan 'baru' (Lubis, 1997).

Beberapa ciri-ciri tersebut adalah pertama dimasukkannya peralatan teori permainan (game theory) sebagai alat analisis.Perbedaan yang paling jelas antara ekonomi industri 'tradisional' dan' 'baru' adalah formalisasi secara eksplisit dari aspek teori permainan terhadap problem yang sedang dikaji. Pada ekonomi industri tradisional, arus sebab-akibat yang terjadi adalah dari struktur melalui perilaku mengalir ke kinerja, misalkan keuntungan diatas normal (kinerja) 
di dalam suatu industri akan diasosiasikan dengan perilaku kolusi yang terjadi akibat konsentrasi yang tinggi (struktur) yang dimungkinkan karena adanya hambatan masuk.

Dengan masuknya teori permainan ke dalam ekonomi industri, maka arus sebab-akibat yang terjadi tidak hanya searah, bahkan dapat mengalir ke segala arah. Hubungannya tidak hanya dari struktur ke perilaku dan kinerja, melainkan himpunan keseluruhan permutasi yang mungkin dari struktur, perilaku, dan kinerja (Norman dan La Manna, 1992).Di dalam ekonomi industri baru, jumlah perusahaan yang beroperasi di pasar (struktur) ditentukan secara endogen dan tergantung pada jenis permainan yang dipilih oleh perusahaan, dalam artian pilihan variabel (harga, output, dll. ), waktu pengambilan keputusan, jumlah permainan yang dimainkan, dan lain sebagainya. Seluruh faktor yang ada di dalam struktur, perilaku dan kinerja menjadi suatu unsuryang ditentukan secara simultan, dan dipengaruhi oleh faktor dasar (fundamental) seperti teknologi (atau kesempatan teknologi), kondisi permintaan, dan derajat kesimetrian dari informasi yang dapat diperoleh. Faktor seperti tingkat hambatan masuk atau keuntunganspesifik yang dimiliki oleh perusahaan sekarang menjadi variabel keputusan yang ditentukan secara endogen oleh keputusan strategis dari perusahaan.

Suatu karakteristik penting kedua dari NIE adalah memberi perhatian lebih pada peran perilaku (conduct) yaitu apresiasi terhadap dimensi strategis dari keputusan perusahaan, dimana perusahaan tidak hanya bereaksi dan beradaptasi terhadap kondisi eksternal, tapi juga berusaha agar lingkungan ekonomi dimana ia berada dapat memberi keuntungan kepadanya, dengan pertimbangan bahwa pesaingnya juga akan melakukan hal yang sama (Norman dan La Manna, 1992).

Dalam setiap perumusan formulasi kebijakan, perusahaan yang bergerak di dalam pasar persaingan tidak sempurna (oligopoli khususnya) harus mempertimbangkan dampak dari implementasi kebijakan tersebut terhadap perusahaan saingannya. Perubahan dari harga atau output yang ditetapkan oleh suatu perusahaan tidak hanya berpengaruh terhadap penjualan dan keuntungannya semata, melainkan dapat mempengaruhi penjualan dan keuntungan saingannya, demikian juga yang terjadi sebaliknya. Setiap perusahaan oligopoli menyadari akan hal ini, sehingga setiap perubahan kebijakan suatu perusahaan akan cepat ditanggapi dan diantisipasi (tergantung pada kelengkapan dan kecepatan informasi yang diperoleh) oleh perusahaan lainnya.

Dari uraian di atas dapat kita simpulkan bahwa terdapat sifat ketergantungan (interdependent) di antara perusahaan-perusahaan yang bergerak di dalam pasar oligopoli. Adanya sifat ketergantungan ini membuat oligopolis berada pada situasi dimana keputusan optimal suatu perusahaan bergantung pada keputusan yang dibuat oleh perusahaan lain. Dengan demikian dalam membuat sebuah keputusan yang terbaik, sebuah perusahaan harus mampu membuat perkiraan yang terbaik (best possible guess) terhadap reaksi yang muncul dari perusahaan saingan, dan sebaliknya keputusan yang dibuat perusahaan tersebut sedapat mungkin untuk sulit diperkirakan oleh perusahaan saingan (Layard dan Walters, 1978). 
Penggunaan teori oligopoli sebagai landasan berpijak menjadi ciri yang kental dari NIE.Meskipun teori-teori yang digunakan umumnya berasal dari teori-teori yang dikembangkan aliran Chicago, namun penggunaannya dalam studi empiris baru dilakukan pada era pendekatan NIE.Karena sifatnya yang banyak 'memperbaiki' studi empiris yang telah dilakukan pada aliran sebelumnya, maka aliran ini juga sering disebut sebagai New Empirical Industrial Organization (NEIO).

Kelemahan pendekatan SCP tradisional dalam analisa empiris, memunculkan pendekatan baru yang berusaha mengurangi penggunaan data akuntansi. Tingkat market power yang dimiliki oleh perusahaan diperoleh dari estimasi terhadap model struktural yang menggambarkan hubungan antara permintaan dan kurva penawaran². Timothy F.Bresnahan (1982) dan Lawrence J.Lau (1982) adalah ekonom pertama yang mengemukakan pendekatan ini berdasarkan kerangka model oligopoli.

Model yang digunakan untuk mengestimasi market power di industri perbankan Indonesia adalah model oligopoli BL yang menggunakan persamaan struktural yang terdiri dari persamaan permintaan (demand function) dan persamaan harga atau penawaran (supply relation).

Diketahui fungsi profit yang dimiliki sebuah perusahaan:

$$
\Pi=P q-C(q, W)-F
$$

dimana $\mathrm{q}=$ output, $\mathrm{P}=$ harga, $\mathrm{C}=$ biaya variabel, $\mathrm{W}=$ variabel eksogen yang mempengaruhi biaya marjinal atau penawaran, dan $\mathrm{F}=$ biaya tetap.

Sedangkan fungsi permintaan pasar yang dihadapi oleh perusahaan adalah:

$$
P=f(Q, Z)=f\left(q_{1}+q_{2}+\ldots+q_{n}, Z\right)
$$

dimana $\mathrm{Z}=$ variabel eksogen yang mempengaruhi permintaan. Dengan memasukkan fungsi permintaan (2) ke dalam persamaan profit (1), maka diperoleh fungsi profit:

$$
\Pi=f(Q, Z) q-C(q, W)-F
$$

Dengan mencari turunan pertama dari fungsi profit (3) terhadap perubahan dari q, maka didapatkan:

2 Selain menggunakan model struktural dari permintaan dan penawaran, estimasi market power juga dapat dilakukan dengan menggunakan metode komparasi statis, yang disebut pendekatan reduced-form. Panzar dan Rosse (1987) menggunakan fungsi pendapatan perusahaan yang telah diturunkan (firm's reduced-form revenue function) untuk menentukan perilaku perusahaan. 


$$
\frac{d \Pi}{d q}=P+f^{\prime}(Q, Z) \frac{d Q}{d q} q-C^{\prime}(q, W)=0
$$

Kemudian dengan mengasumsikan kondisi tersebut adalah rata-rata untuk seluruh perusahaan, maka:

$$
P+f^{\prime}(Q, Z) \frac{d Q}{d q} \frac{1}{n} Q-\sum C^{\prime}(q, W) \frac{1}{n}=0
$$

dan, bila $\quad \lambda=\frac{d Q}{d q} \frac{1}{n} \quad$, maka persamaan (5) dapat ditulis kembali menjadi:

$$
P=-\lambda f^{\prime}(Q, Z) Q+\sum C^{\prime}(q, W) \frac{1}{n}
$$

dimana turunan pertama fungsi permintaan $f^{\prime}(Q, Z)$ menunjukkan pendapatan marjinal dan turunan pertama fungsi biaya $C^{\prime}(q, W)$ adalah biaya marjinal. Kembali ke persamaan $\lambda$ :

$$
\lambda=\left(\frac{d Q}{d q}\right) \frac{1}{n}=\left(\frac{d q+d \sum q_{\text {rest }}}{d q}\right) \frac{1}{n}
$$

dimana ruas $\left(\frac{d q+d \sum q_{\text {rest }}}{d q}\right)$ menunjukkan conjectural variation perusahaan. Conjectural variation dapat didefinisikan sebagai perubahan output keseluruhan perusahaan lain (the rest) yang diantisipasi oleh satu perusahaan sebagai akibat perubahan output perusahaan tersebut (Bikker, 2003).

Mengacu padapersamaan (6) kita dapat menarik kesimpulan terkait kemampuan perusahaan memainkan harga di pasar.

1. Untuk perusahaan yang berada di pasar persaingan sempurna, karena bersifat price taker, maka perubahan output satu perusahaan tidak akan berdampak terhadap output keseluruhan. Hal ini menunjukkan bahwa $\lambda=0$, sehingga persamaan (6) menjadi:

$$
P=\sum C^{\prime}(q, W) \frac{1}{n} \text { atau } P=M C
$$

2. Jika perusahaan-perusahaan yang ada di pasar melakukan kolusi (sempurna) maka peningkatan output satu perusahaan diikuti peningkatan output perusahaan, 


$$
\lambda=\left(\frac{d q+d \sum q_{\text {rest }}}{d q}\right) \frac{1}{n}=\left(1+\frac{(Q-q)}{q}\right) \frac{1}{n}=\frac{Q}{q} \frac{1}{n}=\frac{Q}{q n}=1
$$

sehingga kita mendapatkan $\lambda=1$

3. Jika perusahaan bersaing dalam kerangka Cournot, perubahan output keseluruhan hanya berasal dari perubahan output satu perusahaan, tanpa ada pembalasan (retaliation) dari perusahaan the rest.

$$
d \sum q_{\text {rest }}=0 \quad \text { sehingga } \quad \lambda=\frac{1}{n}
$$

Dengan demikian antara pasar persaingan sempurna dan kolusi sempurna, nilai $\lambda$ akan berkisar antara 0 hingga 1, yang berarti dapat digunakan sebagai indikator untuk menunjukkan tingkat market power atau tingkat persaingan yang ada di pasar. Studi empiris estimasi market poweruntuk mengetahui tingkat persaingan di pasar dapat dilakukan dengan cara mengestimasi variabel $\lambda$ tersebut. Oleh karena itu, untuk menjawab tujuan penelitian, studi ini akan mengestimasi market power industri perbankan Indonesia dengan cara mengestimasi nilai $\lambda$ yang diperoleh dari model oligopoli Bresnahan-Lau (BL).

Seperti yang telah disebutkan sebelumnya, model oligopoli BL merupakan model struktural yang terdiri dari persamaan permintaan dan penawaran. Pembentukan model oligopoli BL dilakukan dengan mengubahsuai persamaan permintaan (2) dan persamaan harga (6) sebelumnya. Dengan menggunakan invers persamaan permintaan (2):

$$
Q=f(P, Z, \alpha)+\varepsilon
$$

dan dengan sedikit penyesuaian pada persamaan harga (6) yang merupakan persamaan kurva penawaran, maka kita mendapatkan:

$$
P=-\lambda f(Q, Z, \alpha)+C(Q, W, \beta)+\eta
$$

Kedua persamaan (7) dan (8) diatas dapat diselesaikan menggunakan two-stage least square (2SLS) dengan harga $P$ dan output $Q$ sebagai variabel endogen. Nilai $\lambda$ yang diperoleh dari estimasi model struktural diatas dapat digunakan untuk menunjukkan seberapa besar market power atau tingkat persaingan yang terjadi di pasar.

Spesifikasi persamaan permintaan yang diperlukan untuk dapat mengestimasi market power adalah dengan cara mencari variabel eksogen (variabel Z) yang tidak hanya menggeser kurva permintaan paralel saja, akan tetapi juga dapat merubah derajat kemiringan (slope) kurva 
permintaan (Bresnahan, 1982)3. Hal ini dapat dilakukan dengan memasukkan variabel instrumental yang merupakan perkalian (cross-term) variabel harga $P$ dengan variabel eksogen Z, menjadi:

$$
Q=\alpha_{0}+\alpha_{1} P+\alpha_{2} Z+\alpha_{3} P Z+\varepsilon
$$

Dengan demikian variabel eksogen $\mathrm{Z}$ tidak hanya menggeser kurva permintaan saja melainkan juga merotasinya ${ }^{4}$. Sedangkan persamaan harga yang digunakan adalah:

$$
P=\frac{-\lambda}{\alpha_{1}+\alpha_{3} Z} \cdot Q+\beta_{0}+\beta_{1} Q+\beta_{2} W+\eta
$$

Dengan menggunakan grafik 1, logika model struktural ini dapat dijelaskan sebagai berikut.Dengan perubahan variabel eksogen $\mathrm{Z}$, intersep dan derajat kemiringan (slope) kurva permintaan akan berubah.Apabila pasar berperilaku kompetitif, rotasi kurva permintaan di sekitar keseimbangan lama tidak akan merubah keseimbangan, sehingga tetap di $\left(\mathrm{Q}_{1}, \mathrm{P}_{1}\right)$. Namun, jika perusahaan memiliki market power, maka akan terjadi perubahan keseimbangan menjadi $\left(\mathrm{Q}_{2}, \mathrm{P}_{2}\right)$. Dengan demikian, rotasi kurva permintaan yang disebabkan oleh variabel eksogen $\mathrm{Z}$, memberikan respon yang berbeda antara pasar yang berperilaku kompetitif dan pasar yang berperilaku monopoli.

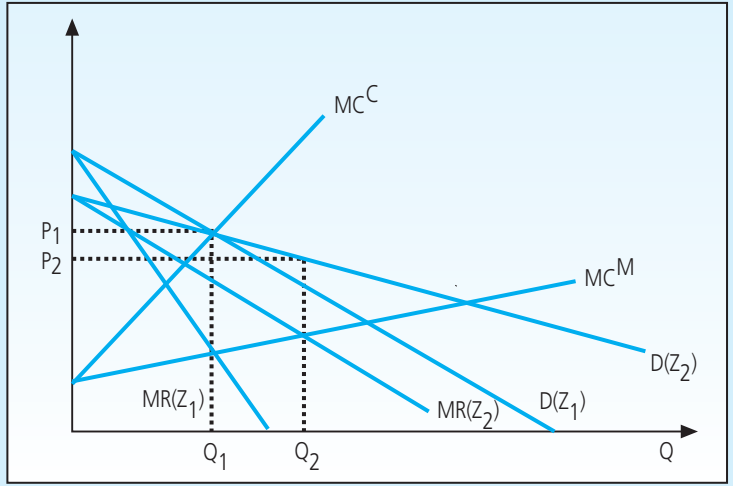

Grafik 1. Perbedaan respon antara pasar kompetitif dengan monopoli

3 Pembuktian dari masalah identifikasi ini dilakukan oleh Lau (1982) yang disebutnya dengan istilah impossibility theorem.

4 Hal ini diperlukan untuk dapat mengestimasi $\lambda$ karena dalam persamaan (8) variable $\lambda$ terkait dengan variable $Q$, sementara variable $\mathrm{Q}$ terdiri dari 2, yakni $\mathrm{Q}$ yang terikat dengan $\alpha$ dan yang terikat dengan $\beta$. Dengan rotasi ini maka dapat dipisahkan $\mathrm{Q}$ yang hanya terikat dengan $\alpha$ dan $\lambda$ saja. 


\section{METODOLOGI}

Market power Penelitian ini menggunakan pendekatan kuantitatif dengan melakukan pengujian inferensial terhadap model empiris yang dibangun. Dasar pemodelan mengacu pada berbagai studi empiris yang mengaplikasikan model oligopoli BL, diantaranya Alexander (1988), Steen dan Salvanes (1999), Toolsema (2002), Bikker dan Haaf (2002), dan Bikker (2003). Tiga yang disebutkan terakhir mengaplikasikan model oligopoli BL di dalam industri perbankan.Berangkat dari tiga model tersebut, .untuk mengestimasi market power di pasar kredit, digunakan dua persamaan struktural, yaitu persamaan permintaan kredit dan persamaan penawaran (fungsi biaya) kredit.

Mengacu pada format persamaan permintaan (9), maka persamaan permintaan kredit yang digunakan adalah:

$$
\begin{aligned}
& K R E D I T=\alpha_{0}+\alpha_{1} S K M K+\alpha_{2} P D B+\alpha_{3} S K M K * P D B+\alpha_{4} S B I 3 \\
& +\alpha_{5} S K M K^{*} S B I 3+\alpha_{6} C A B A N G+\alpha_{7} I N F L A S I+\alpha_{8} K R E D I T_{-1}+\varepsilon
\end{aligned}
$$

dimana KREDIT adalah total kredit yang disalurkan oleh bank umum kepada pihak swasta (claims on private sector). Untuk variabel harga digunakan Suku bunga Kredit Modal Kerja $(\text { SKMK })^{5}$, sedangkan variabel eksogen yang mempengaruhi kredit digunakan variabel PDB Riil (PDB) dengan tahun dasar 1993, sebagai indikator pendapatan masyarakat, variabel Sertifikat Bank Indonesia berjangka waktu 3 bulan (SBI3), variabel jumlah kantor cabang (CABANG), tingkat inflasi (INFLASI) dan kuantitas kredit pada periode sebelumnya (KREDIT ) $^{\text {) }}$.

Terdapat dua variabel interaksi, yaitu interaksi antara suku bunga kredit (SKMK) dengan PDB dan interaksi antara SKMK dengan SBI36. Kedua variabel tersebut digunakan untuk merotasi kurva permintaan.

Dari sisi penawaran, berdasarkan persamaan (10), makapenawaran atau fungsi biaya dari kreditdapat dispesifikasi dengan persamaan berikut:

$$
S K M K=-\lambda \frac{K R E D I T}{\alpha_{1}+\alpha_{3} P D B+\alpha_{5} S B I 3}+\beta_{0}+\beta_{1} \text { KREDIT }+\beta_{2} S D 1+\beta_{3} I N F L A S I+v
$$

dimana variabel eksogen yang digunakan sebagai indikator penentu biaya dari penyaluran kredit perbankan adalah suku bunga deposito berjangka waktu 1 bulan (SD1), dan tingkat inflasi (INFLASI).

5 Selain suku bunga kredit modal kerja, dapat juga digunakan suku bunga kredit investasi, namun karena pergerakan antara kedua suku bunga tersebut searah, maka hampir tidak ada bedanya menggunakan variabel suku bunga kredit modal kerja maupun suku bunga kredit investasi. 
Kedua persamaan struktural di pasar kredit diatas diestimasi dengan menggunakan metode Two Stage Least Square(2SLS). Objek studi adalah pasar kredit bank umum (agregat). Periode yang digunakan dalam model estimasi adalah kuartal pertama tahun 1990 (Q1:1990) hingga kuartal keempat tahun 2004 (Q4:2004). Setelah penyesuaian diperoleh total observasi sebanyak 59 observasi.

Perlu digarisbawahi bahwa terdapat pengujian yang penting untuk dilakukan pada kedua model struktural tersebut, yaitu separability test. Secara teknis, prosedur ini menguji apakah variabel interaksi yang digunakan dalam model bersifat valid atau tidak.

Dalam model empiris terdapat dua buah persamaan struktural yang masing-masing memiliki satu variable interaksi. Untuk dapat mengestimasi market power $\lambda$, maka kondisi yang diperlukan adalah bawah kedua fungsi permintaan pasar kredit tersebut, bersifat non-

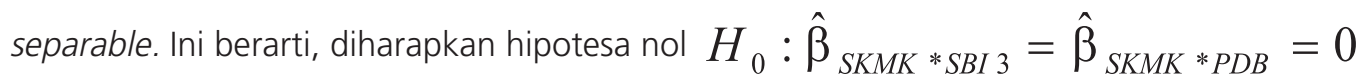

akan ditolak, sehingga kedua variabel interaksi yaitu SKMK*SBI3 dan SKMK*PDB, adalah valid untuk tetap digunakan dalam model.

\section{HASIL DAN ANALISIS}

Hasil estimasi model permintaan kredit (11) dengan menggunakan metode Two Stage Least Square (2SLS), ditampilkan pada Tabel 2. Namun demikian, berlanjutke analisis, sebagaimana disebutkan sebelumnya, estimasi market powerini membutuhkan kondisi kedua persamaan tersebut bersifat non-separable. Hasil pengujian separability yang dilakukan dengan Coefficient Test-Redundant LR Test, diberikan sebagai berikut:

market powerSuku bunga.

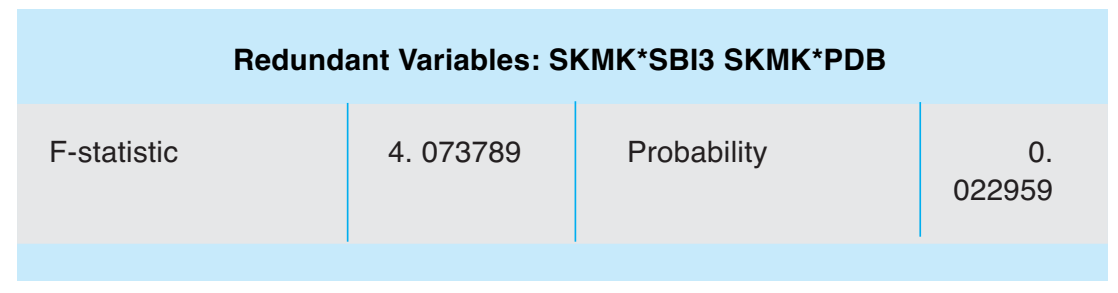

Berdasarkan hasil pengujian di atas, hipotesis nol ditolak pada tingkat keyakinan 5\%. Dengan demikian dapat disimpulkan bahwa fungsi permintaan kredit bersifat non- separable di variabel Sukubunga Sertifikat Bank Indonesia 3-bulan (SBI3) dan variabel pendapatan (PDB).

6 Interaksi dengan variabel eksogen lain, misalnya kantor cabang dan inflasi tidak memperoleh hasil yang signifikan, sehingga tidak dimasukkan ke dalam model. 


\begin{tabular}{|c|c|c|}
\hline \multicolumn{3}{|c|}{$\begin{array}{c}\text { Tabel } 2 . \\
\text { Estimasi Model Permintaan Kredit }\end{array}$} \\
\hline Variabel & Koefisien & T-stat \\
\hline $\begin{array}{l}\text { Konstanta } \\
\text { Suku bunga Kredit Modal Kerja (SKMK) } \\
\text { PDB Riil (PDB) } \\
\text { Sertifikat BI (SBI) 3-Bulan } \\
\text { Kredit }(-1) \\
\text { SKMKSBI3 } \\
\text { SKMKPDB } \\
\text { Kantor Cabang } \\
\text { Inflasi }\end{array}$ & $\begin{array}{r}-1.26 \mathrm{E}+15 \\
5.67 \mathrm{E}+13 \\
11.9359 \\
\text { 1. } 34 \mathrm{E}+13 \\
\text { 1. } 1494 \\
-5.44 \mathrm{E}+11 \\
-0.5439 \\
-2.04 \mathrm{E}+12 \\
\text { 8. } 94 \mathrm{E}+14\end{array}$ & $\begin{array}{r}-2.0204 \\
\text { 2. } 0444 \\
\text { 2. } 0005 \\
\text { 2. } 1306 \\
\text { 7. } 0338 \\
-2.3886 \\
-2.0687 \\
-1.7496 \\
\text { 2. } 9979\end{array}$ \\
\hline $\begin{array}{l}\text { Adjusted } \mathrm{R}^{2} \\
\text { DW Stat } \\
\text { F Stat } \\
\text { Prob (F Stat) }\end{array}$ & $\begin{array}{r}0.9344 \\
2.0124 \\
105.873 \\
0.0000\end{array}$ & \\
\hline
\end{tabular}

Untuk uji t-statistik dengan hipotesis nol $H_{0}: \beta=0$, menunjukkan bahwa nilai t-statistik semua variabel independen menolak hipotesis nol pada tingkat keyakinan 5\%.Dengan kata lain semua variabel independen, baik variabel Suku bunga Kredit Modal Kerja (SKMK), PDB Riil (PDB), Sertifikat Bank Indonesia (SBI) 3-bulan, Kantor cabang (CABANG), tingkat inflasi (INFLASI) dan variabel lag Kredit $(-1)$ maupun variabel interaksi (cross-term) antara SKMK dengan PDB (SKMK*PDB) dan SKMK dengan SBI3 (SKMK*SBI3), secara signifikan (statistically significant) memiliki hubungan dengan variabel dependen yaitu permintaan Kredit.

Pengaruh dari variabel Suku bunga Kredit Modal Kerja (SKMK) terhadap jumlah permintaan Kredit melalui dua jalur, yaitu pengaruh langsung dan tidak langsung. Pengaruh langsung ditunjukkan oleh koefisien SKMK sebesar 5,67E+13, yang bermakna setiap kenaikan 1 persen SKMK akan menaikkan jumlah permintaan Kredit sebesar Rp. 56,7 triliun. Pengaruh tidak langsung ditunjukkan oleh dua variabel interaksi, yaitu SKMK*SBI3 dan SKMK*PDB. Kedua variabel interaksi bernilai negatif, yaitu -5,44E+11 dan -0,5439. Pengaruh total SKMK terhadap Kredit harus memperhitungkan ketiga koefisien tersebut, yaitu sebesar dKredit/dSKMK = $5,67 \mathrm{E}+13-5,44 \mathrm{E}+11 * \mathrm{SBI} 3-0,5439 * \mathrm{PDB}$.

Hal ini menunjukkan bahwa pengaruh SKMK terhadap permintaan Kredit tergantung pada besarnya Sertifikat Bank Indonesia (SBI) 3-bulan dan PDB Riil. Dengan menggunakan nilai rerata ${ }^{7}$ untuk SBI3 dan PDB Riil selama periode observasi, didapatkan pengaruh SKM terhadap jumlah permintaan Kredit sebesar 4,81E+13. Pengaruh positif SKMK terhadap Kredit tersebut

7 Nilai rerata SKMK dan PDB selama periode observasi adalah sebesar 15,73 dan 92.135,04 

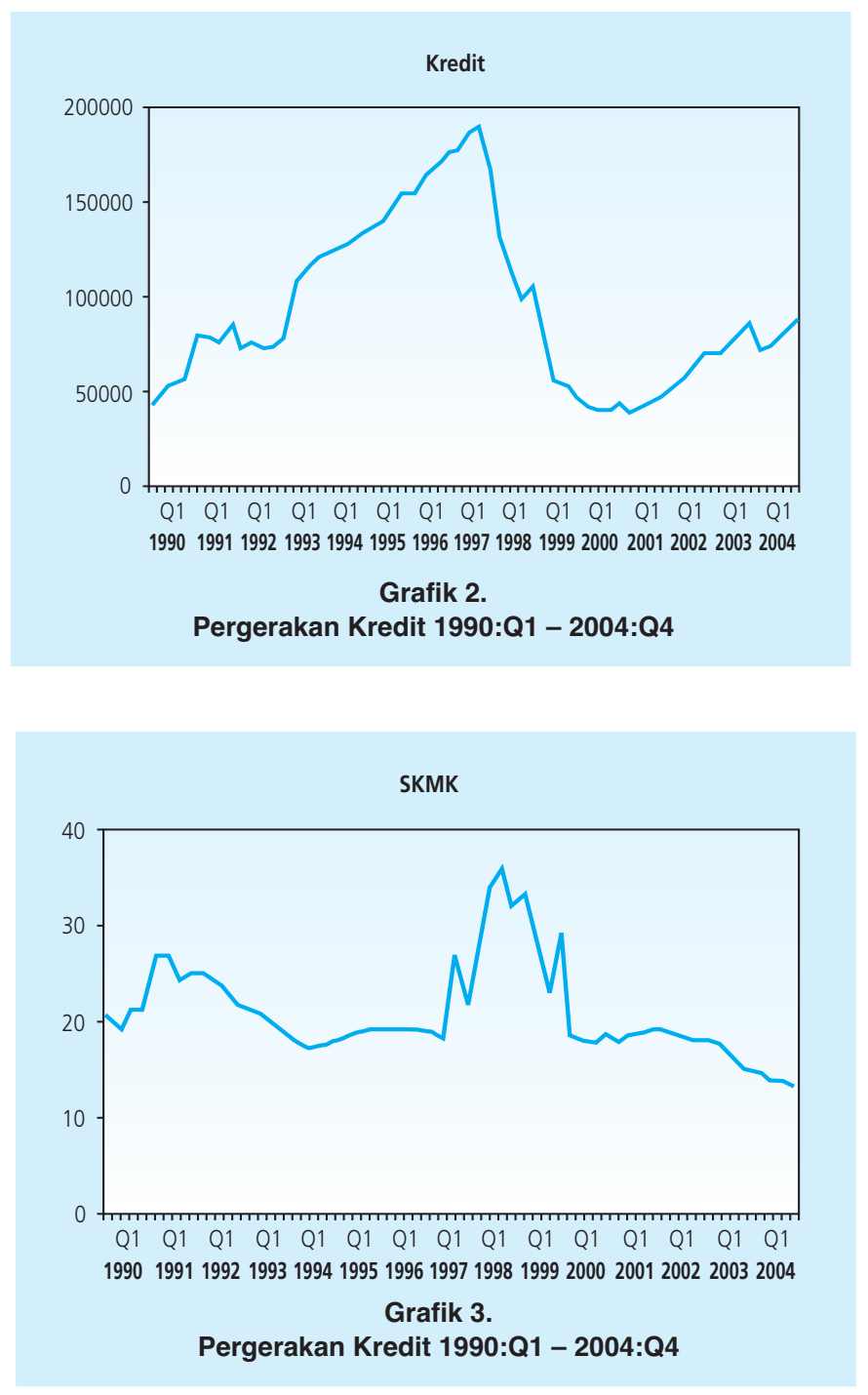

tidak sesuai dengan hipotesis. Pada grafik berikut ini dapat kita lihat pergerakan dari kedua variabel tersebut selama periode observasi.

Dari kedua grafik tersebut terlihat bahwa sebagian periode sebelum krisis ekonomi (19911997) dan sesudah krisis (2002-2004) variabel Kredit dan SKMK memiliki pergerakan yang berlawanan arah. Namun tidak pada periode krisis dimana jumlah kredit mengalami penurunan yang cukup tajam meskipun suku bunga Kredit Modal Kerja juga telah diturunkan. Pola pergerakan searah ini yang menjelaskan pengaruh positif SKMK terhadap Kredit.

Variabel Suku bunga Kredit Modal Kerja (SKMK) berpengaruh positif terhadap jumlah permintaan Kredit.Kenaikan 1 persen suku bunga SKMK akan menaikkan jumlah Kredit sebesar 
Rp 56,7 triliun. Hal ini bertentangan dengan hipotesis karena secara teoritis hubungan antara suku bunga kredit dan permintaan kredit seharusnya bersifat negatif. Kemungkinan penjelasan dari hasil ini adalah bahwa pihak-pihak yang meminta kredit dari perbankan tidak melihat suku bunga kredit sebagai faktor. Artinya meskipun suku bunga kredit tinggi mereka tetap akan meminta kredit dan hal ini dimungkinkan pula karena kebijakan bank yang cukup mudah memberikan kredit, meskipun kelayakannya masih menimbulkan pertanyaan.

Sebagaimana halnya dengan variabel SKMK, pengaruh pendapatan masyarakat yang ditunjukkan oleh PDB juga memiliki pengaruh langsung dan tidak langsung. Pengaruh langsung PDB terhadap jumlah permintaan Kredit sebesar 11,9359, yang bermakna setiap kenaikan 1 Rupiah PDB akan meningkatkan Kredit sebesar 11,9 Rupiah. Sementara pengaruh tidak langsung ditunjukkan oleh koefisien variabel interaksi SKMK*PDB sebesar -0,5439. Pengaruh total dari PDB terhadap Kredit adalah dKredit/dPDB = 11,9359 - 0,5439*SKMK. Dengan menggunakan rerata SKMK, maka pengaruh total PDB terhadap Kredit hanya sebesar 3,38. Pengaruh positif ini telah sesuai dengan hipotesis bahwa jumlah Kredit akan meningkat seiring dengan berkembangnya perekonomian karena kebutuhan untuk investasi dan peningkatan usaha juga akan semakin meningkat.

Variabel pendapatan masyarakat (PDB) berpengaruh positif terhadap permintaan Kredit.Setiap kenaikan 1 Rupiah PDB akan meningkatkan Kredit sebesar 11,9Rupiah. Hal ini sesuai dengan hipotesis bahwa semakin berkembangnya perekonomian maka permintaan Kredit untuk melakukan investasi akan semakin meningkat.

Suku bunga Sertifikat Bank Indonesia (SBI) 3-bulan juga berpengaruh positif terhadap jumlah permintaan Kredit, meskipun besarnya pengaruh SBI3 juga tergantung kepada nilai SKMK, sebagaimana yang ditunjukkan oleh koefisien variabel interaksi SKMK*SBI3. Meskipun

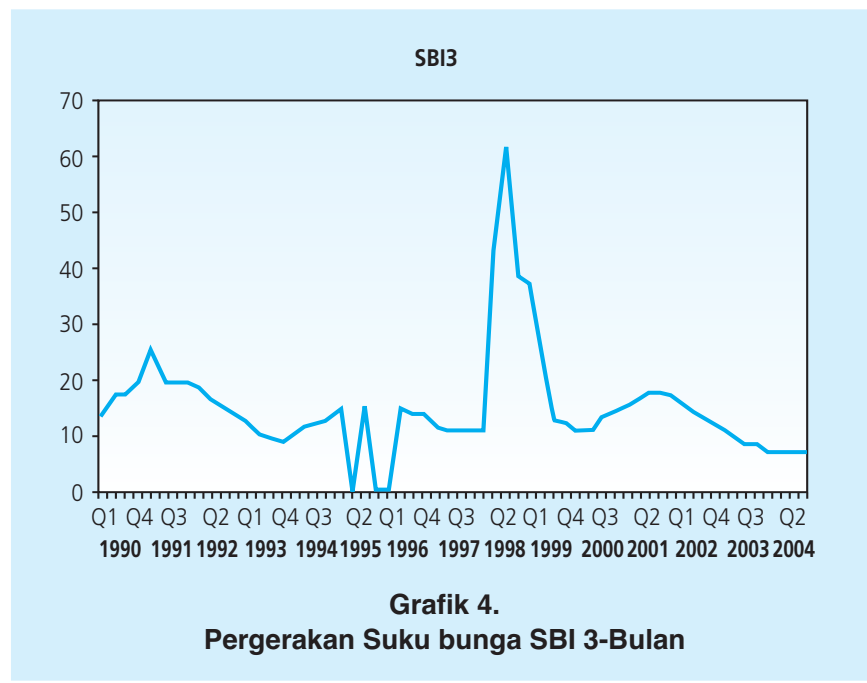


variabel interaksi tersebut bernilai negatif, namun secara keseluruhan (dKredit/dSBI3 = 1,34E+13 - 5,44E+11*SKMK) pengaruh SBI3 terhadap jumlah permintaan Kredit tetap bernilai positif sebesar 1,97E+12. Hubungan searah antara Kredit dan SBI3 menunjukkan bahwa peran SBI3 sebagai salah satu instrumen dalam menggerakkan fungsi intermediasi perbankan tidak bekerja sesuai dengan hipotesis. Ketika SBI diturunkan berarti Sertifikat Bank Indonesia relatif kurang menarik dibandingkan produk perbankan, sehingga diharapkan dana masyarakat yang masuk dan siap untuk diinjeksi ke dalam perekonomian akan meningkat. Namun yang terjadi dalam periode analisa adalah, ketika suku bunga SBI mengalami penurunan, maka jumlah kredit yang disalurkan perbankan juga mengalami penurunan. Dalam grafik berikut, hubungan positif tersebut tampaknya disebabkan kondisi pada periode krisis, dimana setelah mengalami puncaknya pada kwartal ketiga tahun 1998, SBI3 turun secara drastis setelah periode tersebut, namun jumlah Kredit juga tetap mengalami penurunan hingga tahun 2001.

Variabel suku bunga Sertifikat Bank Indonesia (SBI) 3-bulan juga berpengaruh positif terhadap permintaan Kredit. Kenaikan 1 persen SBI3 akan meningkatkan Kredit sebesar Rp 13,4 triliun.

Variabel jumlah Kredit pada periode sebelumnya juga memiliki pengaruh positif. Variabel ini pada dasarnya adalah variabel yang digunakan untuk menunjukkan kecepatan penyesuaian (speed of adjustment lag) dari satu kwartal ke kwartal berikutnya.

Jumlah Kredit pada periode sebelumnya juga berpengaruh positif terhadap permintaan Kredit saat ini. Setiap kenaikan 1 Rupiah Kredit pada periode sebelumnya akan meningkatkan permintaan Kredit periode saat ini sebesar 1, 15 Rupiah.

Jumlah kantor cabang (CABANG) memiliki hubungan negatif dengan jumlah Kredit, dimana setiap kenaikan satu unit kantor cabang akan menurunkan jumlah Kredit sebesar Rp 2,04 triliun. Hal ini bertentangan dengan hipotesis yang menyatakan bahwa semakin banyak jumlah kantor cabang, maka akan semakin besar cakupan pelayanan, yang pada akhirnya akan semakin meningkatkan penyaluran Kredit. Pada awal observasi, jumlah kantor cabang yang tercatat adalah sebesar 2842, nilai ini kemudian meningkat cukup signifikan hingga di akhir periode analisa menjadi 7826. Jika dikaitkan dengan pergerakan Kredit sebagaimana ditampilkan dalam grafik 2, maka hubungan negatif ini lagi-lagi lebih disebabkan pergerakan dalam periode krisis.

Jumlah kantor cabang (CABANG) memiliki hubungan negatif dengan jumlah Kredit.Artinya setiap kenaikan satu unit kantor cabang akan menurunkan jumlah Kredit sebesar Rp 2,04 triliun. Hal ini bertentangan dengan hipotesis yang menyatakan bahwa semakin banyak jumlah kantor cabang, maka akan semakin besar cakupan pelayanan, yang akhirnya akan semakin meningkatkan permintaan akan Kredit.

Variabel tingkat inflasi (INFLASI) berhubungan positif dengan permintaan Kredit. Kenaikan inflasi 1 poin, akan meningkatkan permintaan Kredit sebesar Rp 894 triliun. Dalam 
literatur perbankan dan kredit, hubungan antara inflasi dengan permintaan Kredit dapat berjalan searah maupun berlawanan arah. ${ }^{8}$ Penjelasan terhadap hubungan positif ini adalah perusahaan menggunakan dua sumber dana untuk membiayai modal kerja, yaitu uang (modal sendiri) dan modal pinjaman (dari bank). Tingkat inflasi yang tinggi akan mem-penalti perusahaan jika menggunakan uang lebih banyak, sehingga kredit dari bank akan menjadi lebih diminati.

Variabel tingkat inflasi (INFLASI) berhubungan positif dengan permintaan Kredit.Kenaikan inflasi 1 poin, akan meningkatkan permintaan Kredit sebesar Rp 894 triliun.Sementara itu, kedua variabelinteraksi secara signifikan berpengaruh terhadap permintaan Kredit, namun tidak akan dianalisis secara khusus karena fungsinya disini adalah untuk menentukan besarnya tingkat market power yang diperoleh oleh perbankan Indonesia.

Dalam Tabel 3, ditampilkan hasil estimasi persamaan biaya dari Kredit dengan menggunakan variabel Sukubunga Kredit Modal Kerja (SKMK) sebagai variabel dependen. Dari hasil estimasi pertama, hasil uji korelasi Ljung-Box Q-statistics menunjukkan bahwa hasil estimasi persamaan biaya sukubunga kredit modal kerja (SKMK) mengandung korelasi serial. Dengan menggunakan model ARIMA pada tingkat orde pertama untuk mengatasi masalah korelasi serial, dan White Heteroskedasticity Consistent-Covariance untuk mengatasi masalah heteroskedastisitas, maka persamaan biaya Sukubunga Kredit Modal Kerja (SKMK) setelah dikoreksi adalah seperti terlihat di Tabel 3.

\begin{tabular}{|c|c|c|}
\hline \multicolumn{3}{|c|}{$\begin{array}{c}\text { Tabel } 3 . \\
\text { Hasil Estimasi Penawaran Kredit (dari sisi biaya, setelah dikoreksi) }\end{array}$} \\
\hline Variabel & Koefisien & T-stat \\
\hline Konstanta & 15. 1608 & 11. 9184 \\
\hline Kredit & $-1.11 \mathrm{E}-14$ & -4.0635 \\
\hline Suku bunga Deposito 1-Bulan (SD1) & 0.5501 & 8. 2691 \\
\hline Mark-up $(\lambda)$ & -0.0233 & -1.6961 \\
\hline Inflasi & -40.3296 & -2.1643 \\
\hline $\mathrm{AR}(1)$ & 0.1336 & 0.1372 \\
\hline $\mathrm{MA}(1)$ & 0.1275 & 0.1279 \\
\hline Adjusted R2 & 0.6458 & \\
\hline DW Stat & 1. 7179 & \\
\hline F Stat & 24. 3750 & \\
\hline Prob (F Stat) & 0.0000 & \\
\hline
\end{tabular}

8 Lihat Amidu, 2006 yang menjelaskan studi-studi tentang hubungan inflasi dengan permintaan kredit 
Untuk uji t-statistik dengan hipotesis nol $H_{0}: \beta=0$, menunjukkan bahwa nilai $t$-statistik semua variabel independen menolak hipotesis nol pada tingkat keyakinan $5 \%$ (kecuali variabel mark-up pada tingkat keyakinan 10\%). Dengan kata lain semua variabel independen, baik variabel Kredit, Sukubunga Deposito 1-bulan (SD1), tingkat inflasi (INFLASI) maupun variabel yang menjadi objek utama penelitian ini yaitu variabel Mark-up $(\lambda)$, secara signifikan memiliki hubungan dengan dengan variabel dependen yaitu Sukubunga Kredit Modal Kerja (SKMK).

Variabel jumlah Kredit berpengaruh negatif terhadap suku bunga SKMK. Kenaikan 1 triliun Rupiah jumlah Kredit akan menurunkan SKMK sebesar 1,11 persen. Hubungan negatif ini bertentangan dengan hipotesis dimana seharusnya ketika jumlah Kredit mengalami peningkatan maka biaya pengelolaan kredit akan meningkat sehingga perbankan akan menaikkan suku bunga kredit modal kerja (SKMK). Pengaruh negatif dari jumlah kredit yang disalurkan terhadap SKMK ditengarai terjadi karena perbankan berusaha untuk menurunkan resiko kredit macet (non-performing loans). Pada awal periode (1990) rasio kredit macet berkisar pada angka 4,5\%, namun meningkat menjadi $12 \%$ pada tahun 1994, dan perbankan berhasil menurunkan menjadi 8,8\% pada tahun 1996. Namun rasio ini meningkat lagi setelah adanya krisis. Periode setelah krisis, rasio ini berhasil diturunkan dimana pada tahun 2001 mencapai $12,13 \%$ turun menjadi 4,5\% di tahun 2004 (Desember).

Variabel jumlah Kredit berpengaruh negatif terhadap suku bunga SKMK.Kenaikan 1 triliun Rupiah jumlah Kredit akan menurunkan SKMK sebesar 1,11 persen. Hal ini berbeda dengan hipotesis yang dikemukakan, yang artinya semakin besar jumlah Kredit yang disalurkan, tidak serta merta menambah biaya perbankan yang tercermin lewat suku bunga SKMK, namun sebaliknya perbankan akan menurunkan suku bunganya untuk mengurangi resiko kredit macet (non-performing loans).

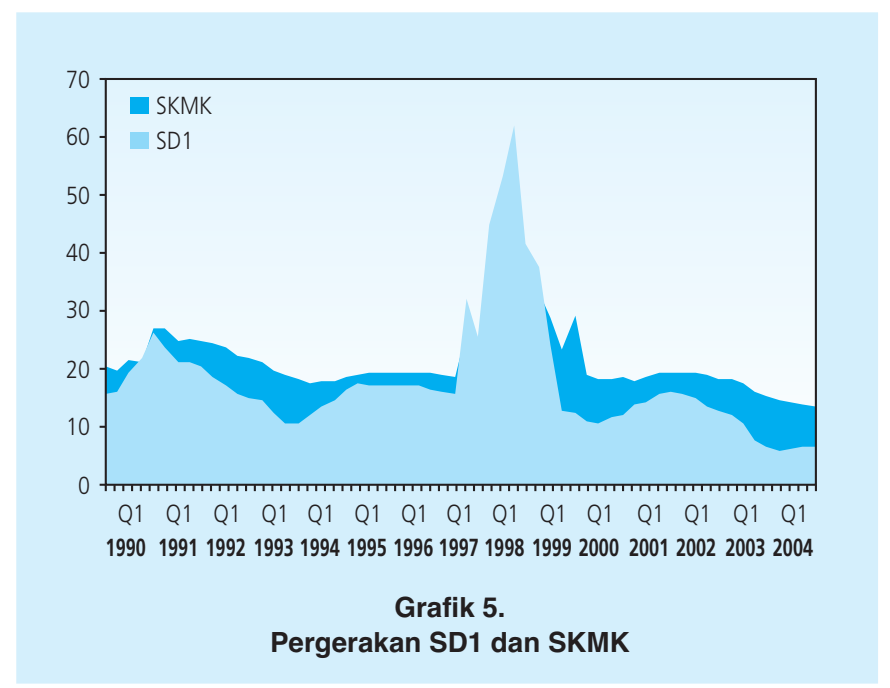


Variabel Suku bunga Deposito 1-bulan (SD1) berpengaruh secara positif terhadap Suku bunga Kredit Modal Kerja (SKMK). Kenaikan SD1 sebesar 1 persen akan menaikkan SKMK sebesar 0,55\%. Hal ini sesuai dengan hipotesis bahwa suku bunga SD1 berperan sebagai biaya utama (cost of fund) dari penyaluran Kredit. Semakin besar perbankan membayar bunga dari dana yang dihimpunnya, maka ia membutuhkan pendapatan yang lebih besar pula. Untuk itulah suku bunga SKMK akan dinaikkan. Hubungan searah ini terlihat pada grafik 5, dimana suku bunga kredit (SKMK) selalu lebih tinggi (kecuali pada periode krisis) dibanding suku bunga deposito 1-bulan, dan memiliki pergerakan yang searah.

Variabel Suku bunga Deposito 1-bulan (SD1) berpengaruh secara positif terhadap Suku bunga Kredit Modal Kerja (SKMK).Kenaikan SD1 sebesar 1 persen akan menaikkan SKMK sebesar 0,55\%. Hal ini sesuai dengan hipotesis bahwa suku bunga SD1 berfungsi sebagai biaya utama dari penyaluran Kredit. Semakin besar perbankan membayar bunga dari dana yang dihimpunnya, maka ia membutuhkan pendapatan yang lebih besar pula. Untuk itulah suku bunga SKMK akan dinaikkan.

Variabel tingkat inflasi (INFLASI) mempengaruhi suku bunga Kredit Modal Kerja (SKMK) secara negatif, dimana setiap kenaikan INFLASI sebesar 1 persen maka akan menurunkan SKMK sebesar 0,4 persen. Hubungan negatif ini bertentangan dengan hipotesis, dimana ketika tingkat inflasi naik, maka cost of fund yang ditanggung perbankan akan naik, karena perbankan menerima pengembalian (repayment) yang lebih kecil dibanding dana yang disalurkan pertama kali. Untuk mencegah hal tersebut maka perbankan akan meningkatkan suku bunga kredit. Namun, dalam paper ini, hubungan antara inflasi dan suku bunga kredit justru bersifat negatif. Penjelasan yang mungkin dari hasil ini adalah adanya hubungan positif antara resiko kredit macet dan tingkat inflasi. Untuk mengurangi resiko kredit macet ketika inflasi meningkat maka perbankan harus menurunkan suku bunga kreditnya. Seperti pada uraian sebelumnya, rasio kredit macet pada periode analisa relatif cukup tinggi, dan baru mengalami penurunan di akhir periode analisa.

Variabel tingkat inflasi (INFLASI) mempengaruhi suku bunga Kredit Modal Kerja (SKMK) secara negatif. Artinya kenaikan tingkat INFLASI sebesar 1 persen maka akan menurunkan SKMK sebesar 0,4 persen.

Yang menjadi objek utama penelitian ini adalah tingkat market power yang diberdayakan (exercised) oleh perbankan nasional Indonesia. Pada pembentukan hipotesis utama penelitian ini, market power pada pasar kredit industri perbankan Indonesia diperkirakan akan tinggi karena memiliki tingkat konsentrasi yang cukup tinggi. Dengan kata lain diperkirakan tingkat persaingan di industri perbankan Indonesia relatif rendah. Dari hasil estimasi pada model diatas diperoleh tingkat market power (mark-up) sebesar 0,023. Dengan nilai market power yang cukup rendah ini membuktikan bahwa hipotesis gabungan (joint hypotheses) yang menyatakan bahwa pemberdayaan market power di pasar kredit perbankan tinggi, yang sekaligus menyatakan bahwa tingkat persaingan realtif rendah tidak dapat diterima. 
Hasil estimasi market power di pasar kredit industri perbankan nasional Indonesia menghasilkan nilai mark-up yang cukup rendah. Tabel di bawah ini menunjukkan perbandingan tingkat market power antara pasar kredit perbankan Indonesia dengan kondisi oligopoli hipotetis.

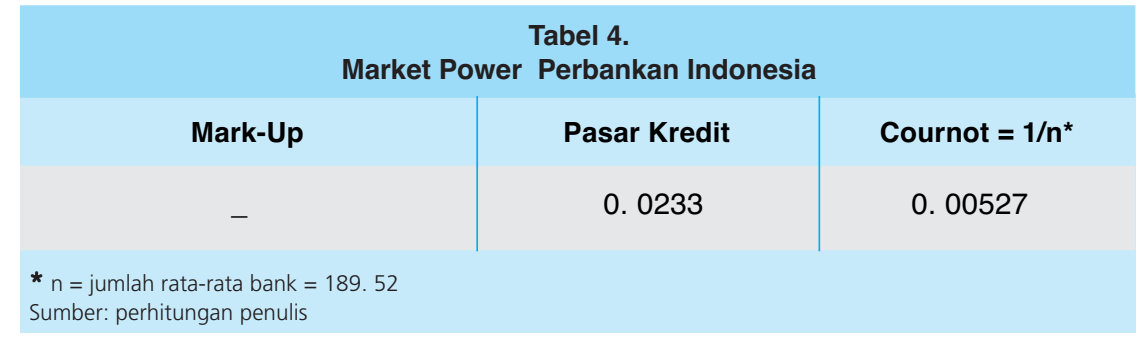

Pada tabel 4 terlihat bahwa nilai mark-up di pasar kredit adalah 0,0233. Berdasarkan uji Wald, nilai ini juga berbeda signifikan (pada tingkat keyakinan 10\%) dengan nol.

$\begin{aligned} & \text { Wald Test: } \\
& \text { Equation: CREDIT MARKET }\end{aligned}$
\begin{tabular}{|l|l|l|l|}
\hline Null Hypothesis: & $\mathrm{C}(4)=0$ & & \\
\hline F-statistic & 2.876983 & Probability & 0.095834 \\
\hline Chi-square & 2. 876983 & Probability & 0.089854 \\
\hline
\end{tabular}

Dengan demikian market power di pasar kredit tidak sama dengan market power di pasar persaingan sempurna.Bahkan jika dibandingkan dengan tingkat market power persaingan Cournot yang sebesar 0,00527. Namun karena nilai mark-up ini masih jauh dibawah 1 (market power monopoli), maka disimpulkan tingkat persaingan di dalamnya juga cukup tinggi.

Dari hasil ini dapat disimpulkan bahwa pemanfaatan (exercising)market power di pasar kredit perbankan Indonesia masih cukup rendah., yang menunjukkanbahwa tingkat persaingan di pasar kredit perbankan Indonesia masih cukup tinggi.

\section{KESIMPULAN}

Tulisan ini ditujukan untuk menguji hipotesis gabungan (joint hyphoteses) mengenai tingkat persaingan dan market power dari pasar kredit di industri perbankan Indonesia dengan menggunakan kerangka model oligopoli Bresnahan-Lau (BL). Market power menunjukkan kemampuan perusahaan-perusahaan di pasar dalam mempengaruhi harga sekaligus menunjukkan tingkat persaingan yang ada di dalam pasar tersebut. 
Model oligopoli BL yang digunakan dalam tulisan ini merupakan model struktural yang menggambarkan hubungan antara permintaan dan kurva penawaran, dimana estimasi market power tidak memerlukan data biaya produksi yang seringkali sulit diperoleh.

Dengan menggunakan model tersebut, diperoleh temuan bahwa tingkat persaingan di pasar kredit industri perbankan Indonesia masih cukup tinggi yang terlihat dari koefisien markup sebesar 0. 0223. Namun meskipun tingkat persaingan cukup tinggi, pasar kredit industri perbankan Indonesia belum dapat dikatakan sebagai pasar persaingan sempurna.

Hasil studi menggunakan model oligopoli BL yang mengestimasi tingkat persaingan dari persamaan struktural memiliki hasil yang berbeda jika dibandingkan mengukur tingkat persaingan berdasarkan tingkat konsentrasi perbankan. Berdasarkan tingkat konsentrasi yang berada pada nilai CR4 sekitar 40an, menunjukkan industri perbankan relatif masih belum kompetitif. Namun, dengan model oligopoli BL terlihat bahwa industri perbankan di pasar kredit relatif sudah cukup kompetitif.

Hasil studi menggunakan model oligopoli BL yang mengestimasi secara langsung market power dari persamaan struktural, mengimplikasikan bahwa indikasi tingkat persaingan industri perbankan Indonesia di pasar kredit dengan menggunakan data struktur pasar adalah tidak tepat. Meskipun secara struktur, industri perbankan Indonesia di pasar kredit cukup terkonsentrasi, namun perilaku bersaing bank-bank umum dalam menyalurkan kredit cukup tinggi. 


\section{DAFTAR PUSTAKA}

Alexander, D. L. , 1988. The Oligopoly Solution Tested. Economic Letters 28, 361-364.

Bikker, J. ,A. , 2003. Testing for Imperfect Competition on EU Deposit and Loan Markets with

Bresnahan's Market power Model. Research Series De Netherlandsche Bank, Amsterdam.

Bikker, J. A. dan K. Haaf, 2002. Competition, Concentration and their Relationship: An Empirical

Analysis of the Banking Industry. Journal of Banking and Finance 26, 2191-2214.

Bresnahan, T. F. , 1982. The Oligopoly Solution Concept is Identified. Economics Letters 10, 87-92.

, 1989. Empirical Studies in Industries with Market power, In: Schmalensee, R.

, Willig, R. D. (Eds. ), Handbook of Industrial Economics, vol. 2. North-Holland, Amsterdam.

Church, J. , dan R. Ware, 2000. Industrial Organization: A Strategic Approach. Boston,

Massachusetts, Irwin McGraw-Hill.

Cole, David C. dan Betty F. Slade, 1996. Building A Modern Financial System: The Indonesian

Experience, Cambridge University Press.

Lau, L. J. , 1982. On Identifying the Degree of Competitiveness from Industry Price and Output

Data. Economics Letters 10, 93-99.

Layard P. R. G dan Walters, A. A. ,1978. Microeconomic Theory. Mac-Graw Hill.

Lubis, Andi F. , 1997. Struktur dan Kekuatan Pasar: Analisa Panel pada Industri Pengolahan 1985 - 1994. Skripsi S1 FEUI (tidak dipublikasikan). Depok.

Norman, G dan La Manna, M (eds), 1992. The New Industrial Economics, Aldershot, Edward Elgar.

Panzar, J. and Rosse, J. , 1987. Testing for 'Monopoly' Equilibrium, Journal of Industrial Economics 35, 443-456.

Steen, F. and Salvanes, K. G. , 1999. Testing for Market power Using a Dynamic Oligopoly Model. International Journal of Industrial Organization 17, 147-177.

Toolsema, L. A. , 2002. Competition in the Dutch Consumer Credit Market. Journal of Banking and Finance 26, 2215-2229. 